\title{
DETECTION OF ENTAMOEBA HISTOLYTICA, GIARDIA LAMBLIA AND CRYPTOSPODIUM SP. INFECTION AMONG DIARRHEAL PATIENTS
}

\author{
Hamida Khanum, Rukhshana Kadir ${ }^{1}$, Tuhinur Arju ${ }^{1}$, Tahmina Ahmed ${ }^{1}$ \\ Mt. Tahmina Karim, Asma Sultana ${ }^{1}$ and Rashidul Huque ${ }^{1}$ \\ Department of Zoology, Parasitology Branch, Faculty of Biological Sciences \\ University of Dhaka, Dhaka-1000, Bangladesh
}

\begin{abstract}
Tri-combo ELISA tests were carried out to determine the prevalence of protozoan parasites (Entamoeba histolytica, Giardia lamblia and Cryptosporidium spp) in 1712 stool samples of diarhoeal patients. Among the samples tested, 118 $(6.89 \%)$ were found positive. The age group 6-14 years were recorded to be more susceptible (14.81\%) and prevalence gradually decreased as the age group increased. Individual Antigen Detection Tests were done on the positive samples and 1 sample was noted to carry E. histolytica (0.06\%), $92(5.37 \%)$ samples with $G$. lamblia and $22(1.29 \%)$ samples with Cryptosporidium spp. Maximum prevalence was recorded in summer $(8.47 \%)$ and rainy seasons $(8.14 \%)$ and highest infections $(10.46 \%)$ were found in the month of September The prevalence of G. lamblia was higher in male $(5.37 \%)$ whereas, the prevalence of Cryptosporidium spp. was higher in female $(1.64 \%)$.
\end{abstract}

Key words: Tri-combo ELISA, Entamoeba histolytica, Giardia lamblia, Cryptosporidium $s p$.

\section{INTRODUCTION}

Diarrheal diseases are extremely common in the developed and developing worlds and are major causes of morbidity and mortality, affecting millions of individuals each year (Guerrant et al., 1990, Mitchell et al., 2008). Diarrhea is a major public health problem worldwide, especially in children. One in ten child deaths result globally from diarrheal disease before their fifth birthday, resulting in about 800000 fatalities worldwide annually, most occurring in sub-Saharan Africa and south Asia (Islam et al.,1983, Liu, et al., 2010). In Bangladesh, 1 in 30 children die of diarrhea or dysentery by his or her fifth birthday (Haque et al. 2003) and one third of the total child death occur is due to diarrhea (Victora et al. 1993). Amoebiasis is an intestinal infection that may or may not be symptomatic. When symptoms are present it is generally known as invasive Amoebiasis. G. lamblia, is the most frequently isolated intestinal protozoa in the world (Khanum et al. 2009, Mhlanga et al., 1992, Chowdhury et al., 1991).

It is a common cause of diarrhea and morbidity, especially in children. Cryptosporidiosis is a diarrheal disease caused by microscopic parasites of the genus Cryptosporidium (Natividad et al., 2008). Once an animal or person is infected, the parasite lives in the intestine and passes through the stool. The parasite is protected by an outer shell (Keusch et al., 1995, Tanyuksel et al., 2001) that allows it to survive outside the body for long periods of time and makes it very resistant to chlorine- based disinfectants (Juranek, 1995).

1 Parasitology Laboratory, International Centre for Diarrheal Disease Research, Bangladesh (ICDDR,B), Mohakhali, Dhaka-1212, Bangladesh. 
The geographical, ecological and socio-economical variations such as, poverty, illiteracy, lack of knowledge of personal hygiene, improper sanitation, contaminated drinking water are the major factors which are responsible for varied rates of prevalence of amoebiasis, giardiasis and cryptosporidiosis (Warhurst and Green, 1989). Control of this organism can prove difficult due to its resistance to standard disinfection methods (e.g., chlorination of water sources) (Dillingham et al., 2002). Lack of rapid and cost-effective diagnostic tools is a major challenge to the surveillance of disease caused by these three pathogens.

Weinke et al.,(1989) reported the prevalence and clinical importance of Entamoeba histolytica in two high-risk groups: travelers returning from the tropics and male homosexuals. For a long time, it was known that people who were infected with $E$. histolytica never developed symptoms and spontaneously clear the infection, i.e. those who were shedding E. histolytica cysts in their stools did not show symptoms of the disease (Ackers 2002).

Members of the genus Cryptosporidium infect epithelial surfaces, especially those along the gut, and can be found in a wide range of vertebrates, including humans. A second species, C. parvum infects the small intestine of an unusually wide range of mammals, including humans, and is the zoonotic species responsible for approximately one-half of human cryptosporidiosis (Huang and White, 2006). A relatively newly discovered species, C. hominis is responsible for the other one-half of human infections. This species is morphologically identical to $C$. parvum, but is more difficult to study due to lack of animal models (Natividad et al. 2008).

Different diagnostic methods are being utilized to detect the intestinal protozoan parasites but there is a need of rapid and cost-effective diagnostic screening methods for a developing country like Bangladesh. The general objective of the study are to determine the prevalence of the common protozoan diarrheal parasites (E. histolytica, G. lamblia, and Cryptosporidium spp.) in the hospital samples of diarrheal patients of icddr,b and to develop a simple low cost technique for identifying these parasites.

\section{MATERIAL AND METHODS}

This study was conducted in the Parasitology laboratory, of International Centre for Diarrheal Disease Research, Bangladesh (icddr,b) at Dhaka. Stoolsamples from 1712 diarhoeal patients were collected and the study was conducted from November 2011 to October 2012.

Tri-combo ELISA: The Tri-combo ELISA is an enzyme immunoassay for the qualitative detection of Giardia lamblia, Cryptosporidium spp. and Entamoeba histolytica antigen in human fecal specimens. The test is indicated for use as a screen for fecal specimens from patients with diarrhea or dysentery to aid in the diagnosis of gastro intestinal infection resulting from giardiasis, 
cryptosporidiosis and amebiasis. The Tri-combo ELISA test serves as a screen to rule out negative specimens and reduce the number of specimens that require additional follow-up testing.

Principle: The Tri-combo ELISA test uses monoclonal and polyclonal antibodies to cell- surface antigens of Giardia lamblia, Cryptosporidium spp. and Entamoeba histolytica. The micro assay plate in the kit contains immobilized monoclonal antibodies against the antigens and the Conjugates consist of polyclonal against the antigens .In the assay, an aliquot of a diluted fecal specimen is transferred to a micro assay well. The immobilized monoclonal antibodies bind the Giardia, Cryptosporidium and Entamoeba histolytica antigens if they are present. Upon addition of Conjugate, it binds to the antigenantibody complex. The cut-off value of these ELISA was $\geq 0.150$ at $450 \mathrm{~nm}$ wavelengths and $\geq 0.090$ at $450 / 630 \mathrm{~nm}$ wavelengths.

A positive test result in the Tri-combo ELISA test indicates that the person is shedding detectable amount of Giardia, Cryptosporidium or E. histolytica antigen. The incidence of Giardia, Cryptosporidium or E. histolytica infection varies significantly between population and geographic regions.

\section{RESULTS AND DISCUSSION}

A total of 1712 stool samples were examined and among them 118 were found positive for three protozoan parasites (E. histolytica, G. lamblia, Cryptosporidium spp.). And among the parasites, the percentages of infection for E. histolytica, G. lamblia and Cryptosporidium spp. were $0.88,80.7$ and 9.29 respectively. The Prevalence of the parasites was $6.89 \%$. Where 74 were male and 44 were female patients. The difference between sexes was statistically non significant, because $p>0.05(p=0.68)$. Klein in 2000 also stated that males are more susceptible to these parasites. It can be concluded that males become more infected compared to females due to their food habit, which are usually taken outside the home and become affected by water born diseases.

The patients were from 0 to above 40 years old. At the age of $0-5$ years the prevalence was $6.83 \%$, in case of $6-14$ years the prevalence was $14.81 \%$, in case of $15-40$ years the prevalence was $7.25 \%$ and in case of 40 above years the prevalence was $3.69 \%$ (Table 01 ). The difference between age groups was statistically significant, because $p<0.05 .(p=0.008)$

The differences in prevalence of infestation were noticeable between different months of the study period (November 2011 to October 2012). The lowest prevalence of infection found in the month of January $(0.71 \%)$ and the highest prevalence found in the month of September (10.46) (Table 02). 
Table 1. Tri-combo ELISA screening of protozoan parasites in the stool samples of male and female diarrheal patients of different age-groups

\begin{tabular}{|c|c|c|c|c|c|c|}
\hline \multirow{2}{*}{$\begin{array}{c}\text { Age } \\
\text { groups } \\
\text { (year) }\end{array}$} & \multicolumn{3}{|c|}{ Male } & \multicolumn{3}{|c|}{ Female } \\
\hline & $\begin{array}{c}\text { No. of } \\
\text { tested } \\
\text { samples }\end{array}$ & $\begin{array}{l}\text { Positive } \\
\text { samples }\end{array}$ & $\begin{array}{c}\text { Prevalence } \\
(\%)\end{array}$ & $\begin{array}{c}\text { No. of } \\
\text { tested } \\
\text { samples }\end{array}$ & $\begin{array}{l}\text { Positive } \\
\text { samples }\end{array}$ & $\begin{array}{c}\text { Prevalence } \\
(\%)\end{array}$ \\
\hline $0-5$ & 530 & 37 & 6.98 & 310 & 21 & 6.58 \\
\hline $6-14$ & 51 & 7 & 13.73 & 30 & 5 & 16.67 \\
\hline $15-40$ & 318 & 23 & 7.23 & 220 & 16 & 7.27 \\
\hline $40+$ & 144 & 7 & 4.86 & 100 & 2 & 2 \\
\hline Total & 1043 & 74 & 7.09 & 669 & 44 & 6.57 \\
\hline
\end{tabular}

The prevalence of the protozoan parasites was higher in summer $(8.47 \%)$ and in rainy season $(8.14 \%)$ and lowest in winter $(3.12 \%)$. It was also observed that, in all the seasons the prevalence was higher in male than female (Table 03).

Table 2: Tri-combo screening of the stool samples from diarrheal patients (both sexes) for the identification of protozoan parasites

\begin{tabular}{ccccccc}
\hline & \multicolumn{3}{c}{$\begin{array}{c}\text { Sex of patients } \\
\text { Male }\end{array}$} & \multicolumn{3}{c}{$\begin{array}{c}\text { Sex of patients } \\
\text { Female }\end{array}$} \\
\hline Sampling months & $\begin{array}{c}\text { No. of } \\
\text { patients }\end{array}$ & $\begin{array}{c}\text { Positive } \\
\text { cases }\end{array}$ & $\begin{array}{c}\text { Prevalence } \\
(\%)\end{array}$ & $\begin{array}{c}\text { No. of } \\
\text { patients }\end{array}$ & $\begin{array}{c}\text { positive } \\
\text { cases }\end{array}$ & $\begin{array}{c}\text { Prevalence } \\
(\%)\end{array}$ \\
\hline November,2011 & 70 & 3 & 4.29 & 49 & 2 & 4.08 \\
December, 2011 & 78 & 3 & 3.58 & 41 & 1 & 2.44 \\
January, 2012 & 89 & 0 & 0 & 61 & 1 & 1.64 \\
February, 2012 & 56 & 3 & 5.36 & 47 & 2 & 4.26 \\
March,12 & 141 & 13 & 9.22 & 84 & 2 & 2.38 \\
April,12 & 146 & 10 & 6.85 & 124 & 15 & 12.9 \\
May,12 & 132 & 13 & 9.85 & 75 & 7 & 9.33 \\
June,12 & 87 & 8 & 9.19 & 49 & 3 & 6.12 \\
July,12 & 80 & 4 & 5 & 45 & 3 & 6.66 \\
August,12 & 51 & 4 & 7.84 & 25 & 2 & 8 \\
September,12 & 58 & 5 & 8.62 & 28 & 4 & 14.29 \\
October,12 & 65 & 8 & 12.31 & 41 & 2 & 4.88 \\
Total & 1043 & 74 & 7.09 & 669 & 44 & 6.57 \\
\hline
\end{tabular}


Table 3: Seasonal variation in the prevalence of Entamoeba histolytica, Giardia lamblia, Cryptosporidium spp. in diarrheal patients

\begin{tabular}{lllllllll}
\hline \multicolumn{2}{c}{ Rainy season (July-October) } & \multicolumn{2}{c}{ Winter (November-February) } & \multicolumn{2}{c}{ Summer (March-June) } \\
\hline $\begin{array}{c}\text { Total } \\
\text { number } \\
\text { of } \\
\text { patients }\end{array}$ & $\begin{array}{c}\text { Number } \\
\text { of } \\
\text { infected } \\
\text { patients }\end{array}$ & $\begin{array}{c}\text { Prevalence } \\
(\%)\end{array}$ & $\begin{array}{c}\text { Total } \\
\text { number } \\
\text { of } \\
\text { patients }\end{array}$ & $\begin{array}{c}\text { Number } \\
\text { of } \\
\text { infected } \\
\text { patients }\end{array}$ & $\begin{array}{c}\text { Prevalence } \\
(\%)\end{array}$ & $\begin{array}{c}\text { Total } \\
\text { number } \\
\text { of } \\
\text { patients }\end{array}$ & $\begin{array}{c}\text { Number } \\
\text { of } \\
\text { infected } \\
\text { patients }\end{array}$ & $\begin{array}{c}\text { Prevalence } \\
(\%)\end{array}$ \\
\hline 254 & 21 & $8.27 \%$ & 283 & 9 & $3.18 \%$ & 506 & 44 & $8.69 \%$ \\
139 & 11 & $7.91 \%$ & 198 & 6 & $3.03 \%$ & 332 & 27 & $8.13 \%$ \\
393 & 32 & $8.14 \%$ & 481 & 15 & $3,12 \%$ & 838 & 71 & $8.47 \%$ \\
\hline
\end{tabular}

The difference between different seasons were statistically significant, because $\mathrm{p}<0.05 .(\mathrm{p}=0.001)$

According to Haque et al. (2012), out of 618 samples from three international sites of the world, 169 samples were positive by Tri-combo ELISA and most of the samples were positive for Giardia spp.

Similar results have been reported by Sharma et al. (2004) and Hamze et al. (2004) that prevalence of E. histolytica for females was higher than males. According to Khanum et al. (1998) the prevalence of G. lamblia in Bangladesh ranges from $4-21 \%$. Khanum et al. (2000) gave a corollary that sex is not related to $G$. lamblia infection, which is actually goes with the present observation. Sayyari et al., (2005), observed that E. histolytica infection was more prevalent in younger age groups. The more susceptible age group was 6-14 years old and as the age progressed, the prevalence kept falling. According to Hossain et al., (1983), the prevalence of giardiasis was higher among the children between the ages of 5-15 years. Hossain et al., (1983) also suggested that the prevalence of Giardiasis declined with the increasing age, which supports the finding of the present study. At that age children are school going and they usually take food and water from outside which is the main cause of being affected by these diarrhea causing agent. Nevine et al., (2012) reported that Cryptosporidium infection is one of the important causes of diarrhea in children below 5 years of age. Walker et al., (2012) Estimated high rate of diarrhea mortality among young children in low and middle income countries

Tri-combo ELISA offers a simple, highly sensitive and specific method of screening fecal specimens to identify protozoan parasites, parasites, eliminating the need for expensive microscopy methods. 


\section{LITERATURE CITED}

ACKERS, J. P. 2002. The diagnostic implications of the separation of Entamoeba histolytica and Entamoeba dispar. J. Bio. sci. 27: 573-578.

CHOUDHURY, G., PRAKASH, V., KUMAR, A., SHAHI, S. K. and SHARMA, M. 1991. Protective immunity to Entamoeba histolytica infection in subjects with antiamoebic antibodies residing in a hyperendemic zone. Scand. J. Infect. Dis. 23: 771-776.

DILlinghAM, R. A., LIMA, A. A. and GUERRANT, R. L. 2002. Cryptosporidiosis: epidemiology and impact. Microbes Infect. 4: 1059 -1066.

GUERRANT, R. L., HUGHES, J. M., LIMA, L. M. and CRANE, J. 1990. Diarrhea in developed and developing countries: magnitude, special settings, and etiologies. Rev. Infect. Dis. 12: 41-50.

HAMZE, M., DABBOUSSI, F., AL-ALI, K. and OURABI, L. 2004. Prevalence of infection by intestinal parasites in north Lebanon. East Mediterr. Health J. 10: 343-348.

HAQUE, R., MONDAL, D., KIRKPATRICK, D., AKHTER, S. and PETRI, Jr. W. A. 2003. Epidemiologic and Clinical Characteristics of acute diarrhea with emphasis on Entamoeba histolytica infections in preschool children in an urban slum of Dhaka, Bangladesh. Am J Trop Med Hyg. 69(4): 398-405.

HAQUE, R., CHRISTY, N.C.V., CADIZ, A.E.D. and NAZIB, F. 2012. "Multisite Performance Evaluation of an Enzyme-Linked Immunosorbent Assay for Detection of Giardia, Cryptosporidium, and Entamoeba histolytica Antigens in Human Stool". Journal of Clinical Biology . 50(5): 1762.

HOSSAIN, M. M., LJUNGSTROM, I., GLASS, R. I., LUNDIN, L., STOLL, B. J. and HULDT, G. 1983. Amoebiasis and giardiasis in Bangladesh: parasitological and serological studies. Trans R Soc Trop Med Hyg. 77(4): 552-4.

HUANG, D. B. and WHITE, A. C. 2006. "An updated review on Cryptosporidium and Giardia". Gastroenterol. Clin. North Am. 35(2): 291-314.

ISLAM, A., STOLL, B.J., LJUNGSTROM, I., BISWAS, J., NAZRUL, H. and HULDT, G. 1983. Giardia lamblia infections in a cohort of Bangladeshi mothers and infants followed for one year. J. Pediatr. 103: 996-1000.

JURANEK, D.D. 1995. Cryptosporidiosis: sources of infection and guidelines for prevention. Clin Infect Dis. 1: 57-61.

KEUSCH, G.T., HAMER, D., JOE, A., KELLEY, M., GRIFFITHS, J. and WARD, H. 1995. Cryptosporidia--who is at risk? Schweiz Med Wochenschr. 125(18): 899-908.

KHANUM, H., CHOWDHURY, S. and SULTANA, S. 1998. Prevalence of Giardia intestinalis among the children of rural areas of Bangladesh. Bangladesh J. Zool. 26(2): 85-89.

KHANUM, H., HAQUE, R. and ZANNAT, R.. 2000. Prevalence of Giardia lamblia infection is asymptomatic rural children in Mirzapur. Univ. J. Zool. Raj. Uni. 19: 79-82.

KHANUM, H., RAHMAN, M., UDDIN, H., ALAM, S., RAHMAN, F. and FARHANA, R. 2009. Intestinal Parasitic Infestation among the Outdoor Patients of Dhaka University Medical Centre, Bangladesh. Univ. j. zool. Rajshahi Univ. 28: 45-49.

KLEIN, S. L. 2000. The effects of hormones on sex differences in infection: from genes to behavior. Neurosci. Biobehav. Rev. 24: 627-638.

LIU, L., JOHNSON, H.L., COUSENS, S., PERIN, J., SCOTT, S., LAWN, J.E., RUDAN, I., CAMPBELL, H., CIBULSKIS, R., LI, M., MATHERS, C. and BLACK, R.E. 2010. Global, regional, and national causes of child mortality: an updated systematic 
analysis for 2010 with time trends since 2000. The Lancet. vol. 379,(9832): 21512161.

MHLANGA, B. R., LANOIE, L. O., NORRIS, H. J., LACK, E. E. and CONNOR, D. H. 1992. Amebiasis complicating carcinomas-a diagnostic dilemma. Am. J. Trop. Med. Hyg. 46: 759-764.

MITCHELL, PIERS D., STERN, ELIEZER, TEPPER, YOTAM. 2008. "Dysentery in the crusader kingdom of Jerusalem: an ELISA analysis of two medieval latrines in the City of Acre (Israel)". Journal of Archaeological Science. 35(7): 1849.

NATIVIDAD, F. F., BUERANO, C. C., LAGO, C. B., MAPUA, C. A., GUZMAN, B. B., SERASPE, E. B., SAMENTAR, L. P. and ENDO T. 2008. Prevalence rates of Giardia and Cryptosporidium among diarrheic patients in the Philippines. Southeast Asian J Trop Med Public Health. 39(6): 9-15.

NEVINE, S., MONA, M. and SAMAR, S. 2012. Detection of Cryptosporidium Infection among Children with Diarrhea . New York Science Journal. 5(7): 68-76.

SAYYARI, A. A., IMANZADEH, F., YAZDI, SAB., KARAMI, H. and Yaghoobi, M. 2005. Prevalence of intestinal parasitic infections in the Islamic Republic of Iran. East. Medit. Health J. 11: 377-380.

SHARMA, B. K., RAI, S. K., RAI D. R. and CHOUDHURY, D. R. 2004. Prevalence of intestinal parasitic infestation in schoolchildren in the northeastern part of Kathmandu Valley, Nepal. Southeast Asian J. Trop. Med. Publ. Health. 35: 501-505.

TANYUKSEL, M., TACHIBANA, H., and PETRI, W. A. JR. 2001. Amebiasis, an emerging disease. J. M. Hughes. ASM Press, Washington, D.C. 197-212 pp.

VICTORA, C.G., HUTTLY, S.R., FUCHS, S.C., BARROS, F.C., GARENNE, M., LEROY, O., FONTAINE, O., BEAU, O., FAUVEAU, V. and CHOWDHURY, H.R. 1993. International differences in clinical patterns of diarrhoeal deaths: a comparison of children from Brazil, Senegal, Bangladesh, and India. J. Diarrhoeal Dis. Res. vol. 11 (1):25-29.

WALKER, C.L.F., ARYEE, M.J., BOSCHI-PINTO, C. and R.E. BLACK. 2012. Estimating diarrhea mortality among young children in low and middle income countries. PloS One. vol. 7, no. 1: pp. e29151.

WARHURST, D. D. and GREEN, D. E. 1989. Protozoa causes of diarrhea. PHLS Microbiol Digest. 5(2): 34-35.

WEINKE, T., FRIEDRICH-JANICKE, B., HOPP, P. and JANITSCHKE, K. 1989. Prevalence and clinical importance of Entamoeba histolytica in two high-risk groups: travelers returning from the tropics and male homosexuals. J. Infect. Dis. 161:1029-1031. 